\title{
Survey on Knowledge, Attitude, Perception and Practice among University Students during the COVID-19 Pandemic
}

\author{
Md. Abdul Wadood ${ }^{1}$, ASMA Mamun ${ }^{2}$, Md. Abdur Rafi ${ }^{3}$, Md. Kamrul Islam ${ }^{2}$, \\ Suhaili Mohd ${ }^{4}$, Lai Lee Lee ${ }^{4}$, Saw Aik ${ }^{4}$, Md. Golam Hossain ${ }^{2 *}$ \\ ${ }^{1}$ Medical Centre, University of Rajshahi, Rajshahi 6205, Bangladesh. \\ ${ }^{2}$ Health Research Group, Department of Statistics, University of Rajshahi, Rajshahi 6205, Bangladesh. \\ ${ }^{3}$ Rajshahi Medical College, Rajshahi 6100, Bangladesh. \\ ${ }^{4}$ Department of Orthopedic Surgery (NOCERAL), Faculty of Medicine, University of Malaya, 50603 Kuala Lumpur, Malaysia.
}

\begin{abstract}
Background: The numbers of infections and death by COVID-19 have continued to rise worldwide and preventive practice has remained to be one of the most effective ways to prevent it. We conducted this study to survey the knowledge, attitude, perception and practice of university students during the early stage of the pandemic in Bangladesh. Methods: This was a cross-sectional study with 305 students from Rajshahi University, conducted between March 11 and March 19, 2020. We developed a questionnaire for collecting information regarding COVID-19 following the instructions and guidelines of WHO and used frequency distribution, Kolmogorov-Smirnov test and Mann-Whitney and KruskalWallis (non-parametric) tests for data analysis. Statistical significance was accepted at $p<0.05$. Results: The knowledge of the students on COVID-19 was of average level; however, more than one-third of them were unwilling to avoid public transport and travel public places with friends and family. Their practice of preventive measures was not at a satisfactory level. More than one-third of them were not keen to stay home and not hesitant to visit crowded places. About half of the students thought the pandemic would not affect their daily activities, and most of them felt it would not affect their study, financial status, fieldwork of their course, or meeting with their friends and relatives. Female students were found more knowledgeable than male ones. Conclusions: The general knowledge of students had an average level on COVID-19, but their attitude, perception and preventive practices were not consistent with their level of education. The authorities should consider the findings while promulgating policies and implementing measures for the prevention of COVID-19.
\end{abstract}

Keywords: Knowledge; Attitude; Practice; Perception; COVID-19; Bangladesh.

\section{Introduction}

Coronavirus disease 2019 (COVID-19) has emerged as one of the most severe pandemics since 1918 and is currently creating panic and a global deadlock in all spheres of life. It has already infected tens of millions of people worldwide, killing thousands of people every day. The first cluster of cases was reported in Wuhan city at the end of 2019, and on January 9, 2020, the Chinese Government identified and published the genomic sequence of the causative pathogen [1]. The primary pathogen was later re-named severe acute respiratory syndrome coronavirus 2 (SARS-CoV-2), and the disease was called COVID-19 [2]. At the end of January 2020, the World Health

* Corresponding author: hossain95@yahoo.com

do) http://dx.doi.org/10.28991/SciMedJ-2021-03-SI-9

$>$ This is an open access article under the CC-BY license (https://creativecommons.org/licenses/by/4.0/).

(C) Authors retain all copyrights. 
Organization (WHO) declared the outbreak a Public Health Emergency of International Concern (PHEIC) [3]. The Chinese Center for Disease Control and Prevention reported that the fatality rate of diagnosed cases was $2.3 \%$, with increased risk in the subjects aged 60 and older (3.6\% in subjects 60-69 years old; $8 \%$ in subjects $70-79$ years old; and $14.8 \%$ in subjects aged 80 and older), and those with comorbidities (case fatality rate in healthy subjects was $0.9 \%$ ) [4]. According to the Corona Virus Resource Centre of John Hopkins University and Medicine, 150,102,206 people were confirmed to have contracted COVID-19 by April 30, 2021, in 192 countries and territories, and 3,161,637 of them died [5]. The world has already experienced the second wave of the pandemic and the numbers of infections and death are still increasing every day.

Mammals and birds were initially suspected as potential reservoirs for SARS-CoV-2 [6-7]. A subsequent study suggested that bats might be the intermediate host [8]. Although definitive evidence showing actual transmission from animal to human is still lacking, the proximity of the early cluster with the animal market in Wuhan city seems to suggest this possibility [9-10]. By the end of January 2020, human-to-human transmission was confirmed.

The virus spreads primarily through droplets of saliva or discharge from the nose of an infected person when she/he coughs or sneezes [11]. WHO reports that the best way to prevent or slow down the spread of COVID-19 is for the public to be well informed about its pattern and mode of transmission, and suggests people wash their hands with soap or use hand sanitizers frequently, avoid touching the face, mouth, nose, and eyes with unwashed or non-sanitized hands, maintaining social distance, and staying home [11]. Individuals should also practice respiratory etiquette such as coughing and sneezing into a flexed elbow, cover the mouth and nose with handkerchiefs, or tissue paper, and wearing masks [11]. Touching of contaminated surfaces is also a possible mode of transmission, since the virus may survive for several hours and days in these areas [12]. Many patients presented with fever, sore throat, and mild to moderate respiratory difficulties and most of them will only experience mild symptoms without treatment [11]. A small percentage of patients may develop severe life-threatening conditions, especially those in the old age group and those with comorbidities like cardiovascular disease, hypertension, diabetes, chronic respiratory disease, and cancer [11].

In a cross-sectional study at the early stage of the COVID-19 pandemic in China, students were found to have satisfactory knowledge, a positive attitude, and a proactive perception of the disease [13]. Among Iranian and Pakistani medical students, COVID-19 related knowledge, attitude, and preventive behaviour were also high [14, 15]. In Jordan, both medical and non-medical students had a high level of knowledge, good practice, and a positive attitude towards COVID-19 [16]. Secondary level students in Italy showed a satisfactory level of knowledge on the clinical manifestation and transmission of COVID-19 and its preventive measures [17]. In many other countries such as India, Egypt, Nigeria, and Malaysia the general people were also reported to have good knowledge and a positive attitude toward COVID-19 [18-21]. However, studies in India and Peru detected rather a high level of misconceptions on the disease although most people have a high level of knowledge on the disease [22, 23].

Bangladesh identified its first confirmed case of COVID-19 on March 8, 2020 [24]. By May 26, 2020, 35,585 cases were confirmed and 501 of them had died [5]. This might be an underestimate, as very few people were being tested in the only laboratory at the Institute of Epidemiology, Disease Control and Research (IEDCR) [25]. Bangladesh is an over-populated country with a population density of 976/sq.km. [26]. According to UNESCO, the adult literacy rate of Bangladesh in 2017 was $72.89 \%$ (male 75.7\% and female 70.09\%) [27]. A survey by UNICEF reported that $59.1 \%$ of the people wash their hands with water and soap only at critical times [28]. Faced with the global pandemic, the government and the concerned non-government organizations have taken some measures to contain the disease outbreak [29-33]. Educational institutions, offices, and markets have been temporarily closed, and the whole country has been put under flexible lockdown several times that did not achieve desired outcome [34]. With the help of some professional organizations, the authorities have made use of both the print and electronic media to conduct publicity on the mode of disease transmission, sign-symptoms of active infection, and strategies to prevent, control, and treat the disease. However, according to media reports, many people were not following the instructions properly [35-36]. Our experience taught us that lack of correct information may lead to misunderstanding or negative perception of efforts by the authorities for the well-being of the whole population. [37].

Until now, effective antiviral therapy is not available for COVID-19 [11]. In the meantime, some vaccines have rapidly been discovered that are being administered throughout the world. However, efficacy, safety and availability of these vaccines have raised some disputes, and continued mutating and evolving of the SARS-CoV-2 have emerged as matters of great concern [38-39]. Moreover, re-infection in recovered COVID-19 patients is not uncommon [40]. We can only try to prevent or mitigate the damage caused by COVID-19 by adhering to the guidelines of WHO which are based on science and evidence-based clinical studies. We would expect the educated and literate public to be more perceptive and have a more correct attitude towards COVID-19. Knowledgeable people showed higher levels of positive attitude and good practice [41]. Majority of slum dwellers, mostly uneducated, were found to have lack of adequate knowledge and poor preventive practices regarding COVID-19 [42]. The healthcare workers, having a high level of education and knowledge of COVID-19 showed a positive attitude towards COVID-19 but a poor practice 
regarding preventive measures [43]. We would expect university students would be motivated and well informed about COVID-19 since they are literate with a high level of education. The authorities need to understand and assess the knowledge, attitude, perception and preventive practices of university students in Bangladesh in face of the ongoing COVID-19 pandemic.

Therefore, we aimed to assess knowledge, attitude, perception and practice regarding COVID-19 among the students of Rajshahi University, Bangladesh.

\subsection{Research Questions}

There are three basic research questions of this study; (i) what is the level of knowledge on COVID-19 among nonmedical university students of Bangladesh during the early stage of the pandemic? (ii) what is the non-medical university students' attitude, perception and practice regarding COVID-19 during the early stage of the pandemic in Bangladesh? (iii) what are the associated factors of knowledge, attitude, perception and practice towards COVID-19 among university students? We hope our present study would provide answers to these questions and thereby help the authorities to properly maintain the guidelines of WHO to prevent COVID-19.

\section{Methods}

\subsection{Study Population and Design}

For this study, 305 healthy volunteers having no mental diseases. Were recruited from the students of the University of Rajshahi, Bangladesh. Out of them, 224 (73.4\%) and 81 (26.6\%) were male and female students. This gender distribution of the population sampling reflected almost the same distribution as was used for another study with Rajshahi University students consisting of $68.18 \%$ males and $31.82 \%$ females [44]. This cross-sectional study was conducted from March 11 to March 19, 2020, during the early period of the COVID-19 pandemic in Bangladesh. Rajshahi University is the second-largest non-medical university in Bangladesh with an approximate number of 38,300 students coming from all over the country for higher education from different socio-economic and cultural statuses. Our target population could be considered as a representative part of non-medical university students in Bangladesh.

\subsection{Questionnaire}

We developed a questionnaire following the instructions and guidelines of WHO (Rapid, simple, flexible behavioural insights on COVID-19) for collecting necessary information from the participants [45]. We divided our questionnaire into five parts: (i) general information of students, (ii) knowledge on COVID-19; it was subdivided into three portions: (a) knowledge on signs and symptoms of COVID-19, (b) knowledge on the protective ways to prevent COVID-19, (c) knowledge on COVID-19 transmission, (iii) perception about COVID-19; it was subdivided into two portions: (a) perception towards COVID-19, and (b) perception about the impact of COVID-19, (iv) attitude towards COVID-19, and (v) practice regarding COVID-19. The draft questionnaire was sent to some experts and finalized after revision following the experts' opinions and suggestions. We could not conduct a pilot study for the post-testing of this questionnaire for a shortage of time. The questionnaire was translated to Bangla (mother tongue of Bangladesh) to make it easily understandable for the participants. After translating, the questionnaire was carefully checked by our two authors for correctly fitting it to COVID-19 issues. The questions or statements used in this study for measuring the level of knowledge, attitude, perception and practice of university students toward COVID-19 were mentioned in Table 1 (knowledge), Table 4 (attitude), Table 5 (practice) and Table 8 (perception).

\subsection{Sample Size Determination}

The population size was known $(34,300)$. In such a case, the following formula would be appropriate to calculate the required sample for this study: $\mathrm{n}=\mathrm{N} /\left(1+\mathrm{Nd}^{2}\right)$, where $\mathrm{n}=$ required sample size, $\mathrm{N}=$ population size, and $\mathrm{d}=$ margin of error (we have considered $\mathrm{d}=0.05$ ) [44]. The formula provided that 396 samples would be sufficient for this study. However, we planned to collect data from 500 students.

\subsection{Sampling and Data Collection}

Mixed sampling (probability and non-probability) was utilized in this study for selecting our required samples [46]. In the first step, we selected three departments from the Science faculty using random sampling (by lottery); the departments were: (i) Statistics, (ii) Mathematics, and (iii) Physics. In the second step, one academic year was selected randomly from each selected department; these were: (i) the second year from Statistics, (ii) the first year from Mathematics, and (iii) the first year from Physics. In the third step, random sampling was used for collecting information from the students of the selected years of the selected departments. Students were taken to a particular classroom and briefed about the objectives of the study. Written consents of the agreed students were taken. They 
were prohibited from using their cell phones, laptops, and the internet. They filled up the questionnaire in the presence of the researchers without discussion with their friends. A total number of 242 students had been interviewed using this procedure. We had a plan to collect data from the rest of 258 students selected from other faculties but we could not continue this procedure as the university was locked down for the COVID-19 outbreak and all students had left the university campus. We tried to fulfil the required sample size and collected data from another 63 Rajshahi university students who were living in private residences outside the campus using non-probability random sampling. Suddenly, the whole country was locked down in fear of aggravating the COVID-19 outbreak situation and we had to stop data collection. Finally, a total number of 305 students were considered as the sample for the present study. A flow chart was shown below in Figure 1.

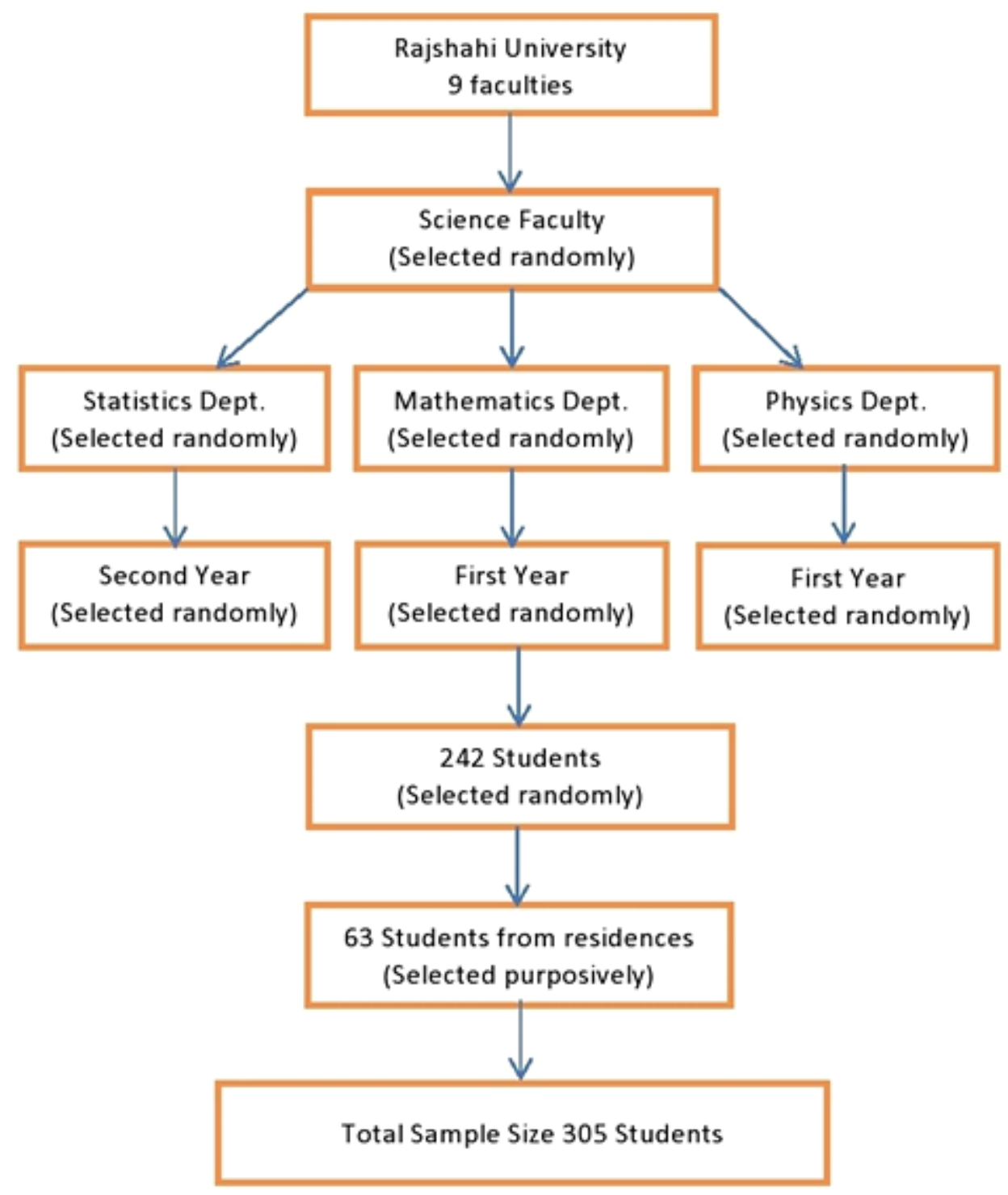

Figure 1. Sampling technique

\subsection{Statistical Analysis}

All collected data were entered into SPSS (IBM, version 21) for analysis. The level of students' knowledge on COVID-19, and the percentage of their attitude, practice and perception based on the selected questions were determined by frequency distribution. The normality of the data (number of corrected answers) was checked by the Kolmogorov-Smirnov test. This non-parametric test and histogram showed that our data were not normally distributed. We used Mann-Whitney and Kruskal-Wallis (non-parametric) tests to find the significance of the difference in the number of correct answers between two and more than two groups respectively. Statistical significance was accepted at $\mathrm{p}<0.05$. 


\section{Results}

\subsection{Demographic Profiles}

Of the 305 University students, $73.4 \%$ were male and $26.6 \%$ were female. Their age ranged from 17 to 28 years, with mean and median ages of $20.66 \pm 1.78$ and 20 years respectively. More than half of the students $(51.1 \%)$ came from rural areas. Half of the students' fathers (50\%) were highly educated, and only a quarter $(25.1 \%)$ of students had highly educated mothers. More than three-quarters (76.1\%) of students came from nuclear families (Table 3).

\subsection{General Knowledge of COVID-19}

\subsubsection{Frequency of Questions Answered}

Most (91.8\%) of the students answered that fever was a symptom of COVID-19, followed by dry cough (81.3\%), difficulty in breathing $(78.4 \%)$, a general unwell feeling $(77.7 \%)$, shortness of breath $(70.8 \%)$, headache $(55.1 \%)$, running nose $(54.8 \%)$ and sore throat $(49.8 \%)$. Close to half $(43 \%)$ of the students considered chest pain as a symptom, but most of them did not $(16.4 \%)$ relate it to gastrointestinal disturbance like diarrhoea (Table 1). On reducing the risk to be infected with COVID-19, most of the students $(>90 \%)$ knew that maintaining hand hygiene, avoiding touching the face, proper behaviour when coughing, and wearing of face mask were effective measures. There were also those with unproven beliefs. More than a third $(39.7 \%)$ of the students believed that eating rice and vegetables could give protection from COVID-19, and a smaller number (16.1\%) did not think that maintaining distance from infected persons would confer any protection against disease transmission (Table 1). Regarding the knowledge on disease transmission, more than $90 \%$ of the students believed that COVID-19 could spread from person to person, and associated the disease transmission with coughing and sneezing. Many believed that the disease could be transmitted from animal to human $(78.7 \%)$, and by touching contaminated surfaces $(78.0 \%)$. We also noted that many students felt they might contract COVID-19 from flu patients $(84.9 \%)$, or by drinking contaminated water or food $(52.2 \%)$ (Table1).

Table 1. General knowledge of COVID-19 among students

\begin{tabular}{|c|c|c|c|}
\hline \multicolumn{4}{|c|}{ What are the signs and symptoms of COVID-19? } \\
\hline & Yes, N (\%) & No, $N(\%)$ & Don't know, N (\%) \\
\hline A general feeling of unwell & $237(77.7)$ & $46(15.1)$ & $22(7.2)$ \\
\hline Fever & $280(91.8)$ & $22(7.2)$ & $3(1.0)$ \\
\hline Dry cough & $248(81.3)$ & $44(14.4)$ & $13(4.3)$ \\
\hline Sore throat & $152(49.8)$ & $93(30.5)$ & $60(19.7)$ \\
\hline Short of breath & $216(70.8)$ & $57(18.7)$ & $32(10.5)$ \\
\hline Difficulty in breathing & $239(78.4)$ & $44(14.4)$ & $22(7.2)$ \\
\hline Headache & $168(55.1)$ & $95(31.1)$ & $42(13.8)$ \\
\hline Running nose & $167(54.8)$ & $96(31.5)$ & $42(13.8)$ \\
\hline Diarrhoea & $50(16.4)$ & $221(72.5)$ & $34(11.1)$ \\
\hline Chest pain & $134(43.9)$ & $129(42.3)$ & $42(13.8)$ \\
\hline \multicolumn{4}{|c|}{ What is the protective way to COVID-19? } \\
\hline $\begin{array}{l}\text { Avoid contact with people who have respiratory illness symptoms such as coughing, } \\
\text { sneezing, and flu }\end{array}$ & $266(87.2)$ & $36(11.8)$ & $3(1.0)$ \\
\hline Avoid touching nose, mouth and eyes with unwashed hands & $296(97.0)$ & $8(2.6)$ & $1(0.3)$ \\
\hline Always perform handwashing with soaps and water & $298(97.7)$ & $5(1.6)$ & $2(0.7)$ \\
\hline Always eat fully cooked eggs and meat & $227(74.4)$ & $62(20.3)$ & $16(5.2)$ \\
\hline Always eat rice and vegetables & $121(39.7)$ & $146(47.9)$ & $38(12.5)$ \\
\hline Clean and disinfect objects and surface & $244(80.0)$ & $36(11.8)$ & $25(8.2)$ \\
\hline Cover mouth and nose with tissue or handkerchief when cough or sneeze & $286(93.8)$ & $13(4.3)$ & $6(2.0)$ \\
\hline $\begin{array}{l}\text { Wear clean surgical masks when you have respiratory illness symptoms such as } \\
\text { coughing, sneezing, and flu }\end{array}$ & $280(91.8)$ & $19(6.2)$ & $6(2.0)$ \\
\hline Don't need to maintain distance from infected persons & $49(16.1)$ & $248(81.3)$ & $8(2.6$ \\
\hline \multicolumn{4}{|c|}{ Knowledge of COVID-19 transmission } \\
\hline COVID-19 can be spread from animal to human & $240(78.7)$ & $35(11.5)$ & $30(9.8)$ \\
\hline Novel coronavirus can be spread from person to person & $296(97.0)$ & $7(2.3)$ & $2(0.7)$ \\
\hline A person can get COVID-19 through coughing or sneezing from a COVID-19 person & $287(94.1)$ & $11(3.6)$ & $7(2.3)$ \\
\hline A person can get COVID-19 through the mosquito bite & $33(10.8)$ & $236(77.4)$ & $36(11.8)$ \\
\hline A person can get COVID-19 through water and food & $160(52.5)$ & $107(35.1)$ & $38(12.5)$ \\
\hline A person can get COVID-19 through objects contaminated with coronavirus & $238(78.0)$ & $31(10.2)$ & $36(11.8)$ \\
\hline $\begin{array}{l}\text { A person can get COVID-19 by touching other person with flu viruses and then } \\
\text { touching their mouth or nose }\end{array}$ & $259(84.9)$ & $32(10.5)$ & $14(4.6)$ \\
\hline
\end{tabular}




\subsubsection{Level of Knowledge}

Table 2 shows the level of knowledge on COVID-19 among university students. Only 3.9\% of students provided correct answers to all questions regarding signs and symptoms of COVID-19, while more than $46 \%$ of them answered 6-7 questions correctly. About half of the students (49.5\%) knew all the correct ways (7 questions) of avoiding infection while $31.8 \%$ correctly answered 6 out of the 7 questions. On the modes of disease transmission, $35.1 \%$ of students knew all the correct answers (6 questions), while $34.1 \%$ answered 5 of the 6 questions correctly (Table 2).

Table 2. Level of knowledge on COVID-19 among university students

\begin{tabular}{|c|c|c|c|c|c|}
\hline Question & $\begin{array}{l}\text { Number of } \\
\text { correct answers }\end{array}$ & $\begin{array}{c}\text { Level of knowledge, } \\
\text { N }(\%)\end{array}$ & Question & $\begin{array}{l}\text { Number of } \\
\text { correct answer }\end{array}$ & $\begin{array}{c}\text { Level of knowledge, } \\
\text { N (\%) }\end{array}$ \\
\hline \multirow{10}{*}{$\begin{array}{l}\text { What are the signs and } \\
\text { symptoms of Covid- } 19 ?\end{array}$} & 0 & $3(1.0)$ & \multirow{6}{*}{$\begin{array}{l}\text { What is the protective } \\
\text { way to avoid COVID } \\
\text { infections? }\end{array}$} & 2 & $2(0.3)$ \\
\hline & 1 & $5(1.6)$ & & 3 & $5(1.6)$ \\
\hline & 2 & $7(2.3)$ & & 4 & $14(4.6)$ \\
\hline & 3 & $13(4.3)$ & & 5 & $37(12.1)$ \\
\hline & 4 & $36(11.8)$ & & 6 & 97 (31.8) \\
\hline & 5 & $53(17.4)$ & & 7 & $151(49.5)$ \\
\hline & 6 & $82(26.9)$ & \multirow{6}{*}{$\begin{array}{l}\text { Knowledge of COVID- } \\
19 \text { transmission }\end{array}$} & 1 & $1(0.3)$ \\
\hline & 7 & $62(20.3)$ & & 2 & $6(2.0)$ \\
\hline & 8 & $32(10.5)$ & & 3 & $31(10.2)$ \\
\hline & \multirow[t]{3}{*}{9} & $12(3.9)$ & & 4 & $56(18.4)$ \\
\hline & & & & 5 & $104(34.1)$ \\
\hline & & & & 6 & $107(35.1)$ \\
\hline
\end{tabular}

\subsubsection{Level of Knowledge by Characteristics of the Respondents}

The average number of $5.76 \pm 1.76$ questions (out of 10) on signs and symptoms, $6.22 \pm 0.98$ questions (out of nine) on protective ways to avoid COVID-19, and 4.89 \pm 1.08 questions (out of seven) on the transmission of COVID-19 were correctly answered by the students. Mann-Whitney test demonstrated that female students gave more correct answers to the questions on how to avoid being infected, and knowledge on disease transmission, compared to male students $(\mathrm{p}<0.05)$. There was no significant difference in the number of correct answers between students from urban and rural areas, nuclear and joint families, and the education level of their parents (Table 3 ).

Table 3. Average knowledge on symptoms, protective ways, and the transmission of COVID-19 by different characteristics of participants

\begin{tabular}{|c|c|c|c|}
\hline Characteristics & $\begin{array}{l}\text { Signs and symptoms, } \\
\text { Mean } \pm S D, 5.76 \pm 1.76\end{array}$ & $\begin{array}{c}\text { Protective way to avoid COVID-19, } \\
\text { Mean } \pm \text { SD }, 6.22 \pm 0.98\end{array}$ & $\begin{array}{c}\text { Knowledge on transmission, } \\
\text { Mean } \pm \text { SD }, 4.89 \pm 1.08\end{array}$ \\
\hline Gender & M-W test; value $=8173^{\mathrm{n}}$ & M-W test; value $=7587^{*}$ & M-W test; value $=7534^{*}$ \\
\hline Male, 224(73.4) & $5.68 \pm 1.79$ & $6.11 \pm 1.05$ & $4.80 \pm 1.11$ \\
\hline Female, 81(26.6) & $5.99 \pm 1.66$ & $6.48 \pm 0.67$ & $5.14 \pm 0.96$ \\
\hline Original residence & M-W test; value $=11070^{\mathrm{n}}$ & $\mathrm{M}-\mathrm{W}$ test; value $=11128^{\mathrm{n}}$ & M-W test; value $=11570^{\mathrm{n}}$ \\
\hline Urban, 149(48.9) & $5.69 \pm 1.75$ & $6.25 \pm 0.98$ & $4.91 \pm 1.01$ \\
\hline Rural, 156(51.1) & $5.83 \pm 1.77$ & $6.19 \pm 0.98$ & $4.87 \pm 1.15$ \\
\hline Type of family & M-W test; value $=79430^{\mathrm{n}}$ & M-W test; value $=8283^{\mathrm{n}}$ & M-W test; value $=0.948^{\mathrm{n}}$ \\
\hline Nuclear, 232(76.1) & $5.79 \pm 1.77$ & $6.20 \pm 1.00$ & $4.89 \pm 1.07$ \\
\hline Joint, 73(23.9) & $5.67 \pm 1.72$ & $6.27 \pm 0.90$ & $4.89 \pm 1.11$ \\
\hline Fathers' education & $\begin{array}{l}\text { K-W test, Chi-square } \\
\text { value }=1.074^{\mathrm{n}}\end{array}$ & $\begin{array}{l}\text { K-W test, Chi-square } \\
\text { value }=1.712^{\mathrm{n}}\end{array}$ & $\begin{array}{l}\text { K-W test, Chi-square } \\
\text { value }=5.372^{\mathrm{n}}\end{array}$ \\
\hline Uneducated, 25(8.2) & $5.28 \pm 2.23$ & $6.12 \pm 0.93$ & $5.28 \pm 0.79$ \\
\hline Primary, 48(15.7) & $5.79 \pm 1.69$ & $6.08 \pm 1.15$ & $4.71 \pm 1.11$ \\
\hline Secondary, 86(28.2) & $5.92 \pm 1.69$ & $6.28 \pm 0.99$ & $4.80 \pm 1.09$ \\
\hline Higher, 146(47.9) & $5.74 \pm 1.73$ & $6.25 \pm 0.92$ & $4.94 \pm 1.09$ \\
\hline Mothers' education & 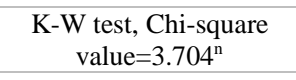 & $\begin{array}{l}\text { K-W test, Chi-square } \\
\text { value }=0.832^{\mathrm{n}}\end{array}$ & $\begin{array}{l}\text { K-W test, Chi-square } \\
\quad \text { value }=3.228^{\mathrm{n}}\end{array}$ \\
\hline Uneducated, 36(11.8) & $5.22 \pm 2.14$ & $6.17 \pm 0.91$ & $4.83 \pm 1.06$ \\
\hline Primary, 65(21.3) & $5.94 \pm 1.60$ & $6.18 \pm 0.97$ & $4.69 \pm 1.16$ \\
\hline Secondary, 126(41.3) & $5.87 \pm 1.76$ & $6.22 \pm 1.00$ & $4.95 \pm 1.09$ \\
\hline Higher, 78(25.6) & $5.67 \pm 1.67$ & $6.27 \pm 0.99$ & $4.99 \pm 1.00$ \\
\hline
\end{tabular}

N.B.: SD: Standard deviation; M-W: Mann-Whitney; K-W: Kruskal-Wallis; *: 5\% level of significance; n: non-significance. 


\subsection{Attitude toward COVID-19}

Most of the students $(82.0 \%)$ were afraid to contact people with flu symptoms. Many students were concerned about the eating habits, like eating wildlife animals' meat (80.7\%), eating raw food (74.8\%), and eating from hawker centres (73.4\%). Others were concerned about social activities, like going abroad with friends and family (75.1\%), going out to crowded places $(73.4 \%)$, contacting those who just returned from overseas $(72.1 \%)$, and to a lesser extent going out to public places with friends and family (60\%). About half of them $(48.5 \%)$ were concerned about taking public transports (Table 4).

Table 4. Attitude toward COVID-19 among university students

\begin{tabular}{|c|c|c|c|}
\hline Level of fearful & Yes & No & Occasionally \\
\hline $\begin{array}{l}\text { Are you afraid to contact people who have flu symptoms such as } \\
\text { cough, running nose, sneezing, and fever? }\end{array}$ & $250(82.0)$ & $34(11.1)$ & $21(6.9)$ \\
\hline Are you afraid to eat outside food from hawker centers? & $224(73.4)$ & $63(20.7)$ & $18(5.9)$ \\
\hline Are you afraid of eating raw food? & $228(74.8)$ & $62(20.3)$ & $15(4.9)$ \\
\hline Are you are afraid of eating wildlife animal's meat? & $246(80.7)$ & $46(15.1)$ & $13(4.3)$ \\
\hline $\begin{array}{l}\text { Are you afraid to contact your friends and relatives who just back } \\
\text { from overseas? }\end{array}$ & $220(72.1)$ & $60(19.7)$ & $25(8.2)$ \\
\hline Are you afraid to go to crowded places? & $224(73.4)$ & $57(18.7)$ & $24(7.9)$ \\
\hline Are you avoiding going out to public places with friends and family? & $183(60.0)$ & $93(30.5)$ & $29(9.5)$ \\
\hline Are you avoiding going abroad with friends and family? & $229(75.1)$ & $67(22.0)$ & $9(3.0)$ \\
\hline $\begin{array}{l}\text { Are you avoiding taking public transport (e.g. taxi, bus, train, and } \\
\text { airplane)? }\end{array}$ & $148(48.5)$ & $127(41.6)$ & $30(9.8)$ \\
\hline
\end{tabular}

\subsection{The Practice of Preventive Measures}

It was observed that $89.5 \%$ of the students were currently performing frequent hand washing. Slightly more than half $(59.7 \%)$ of them would stay at home to avoid crowded places, and if they had to go out, only half would wear face masks (53.8\%). When asked about a healthy lifestyle, most of them (82.3\%) answered that they were agreeable with taking nutritious food, doing regular exercise, and have adequate rest to reduce the risk to be infected. (Table 5).

Table 5. Practice of COVID-19 preventive measures among university students

\begin{tabular}{|c|c|c|c|}
\hline Practice to avoid COVID-19 & Yes & No & Occasionally \\
\hline Do you wash your hands frequently and thoroughly? & $273(89.5)$ & $18(5.9)$ & $14(4.6)$ \\
\hline Are you are wearing surgical face masks when out in public? & $164(53.8)$ & $121(39.7)$ & $20(6.6)$ \\
\hline Will you stay at home and avoid going to crowded places? & $182(59.7)$ & $98(32.1)$ & $25(8.2)$ \\
\hline $\begin{array}{l}\text { Will you take medicine (conventional or traditional medicine) if you } \\
\text { feel your body unwell? }\end{array}$ & $203(66.6)$ & $83(27.2)$ & $19(6.2)$ \\
\hline $\begin{array}{l}\text { Will you perform a healthy lifestyle (eat nutritious food, exercise } \\
\text { regularly, and get enough rest or sleep) to maintain your body healthy } \\
\text { and to avoid infection? }\end{array}$ & $251(82.3)$ & $32(10.5)$ & $22(7.2)$ \\
\hline
\end{tabular}

\subsection{Level of Attitude and Practice}

On the attitude towards COVID-19, only $21 \%$ of students were able to answer all 9 questions correctly, while $36.4 \%, 29.2 \%$ and $12.5 \%$ showed a positive attitude with correctly answering 7-8, 4-6, and 1-3 questions respectively. On personal practices, only $24 \%$ of students were performing all the correct practices, while $54.1 \%$ and $20.4 \%$ of students were doing between 3-4 and 1-2 correct practices (Table 6).

Table 6. Level of positive attitude and good practice on COVID-19 among university students

\begin{tabular}{|c|c|c|c|c|c|}
\hline Attitude & $\begin{array}{c}\text { Number of positive } \\
\text { answers }\end{array}$ & $\begin{array}{l}\text { Level of positive } \\
\text { attitude, } N(\%)\end{array}$ & Practice & $\begin{array}{c}\text { Number of positive } \\
\text { answers }\end{array}$ & $\begin{array}{c}\text { Level of good } \\
\text { practice, } N(\%)\end{array}$ \\
\hline \multirow{10}{*}{$\begin{array}{l}\text { Attitude toward } \\
\text { COVID-19 }\end{array}$} & 0 & $3(1.0)$ & \multirow{6}{*}{$\begin{array}{c}\text { Practice toward } \\
\text { COVID-19 }\end{array}$} & 0 & $3(1.0)$ \\
\hline & 1 & $5(1.6)$ & & 1 & $13(4.3)$ \\
\hline & 2 & $24(7.9)$ & & 2 & $49(16.1)$ \\
\hline & 3 & $9(3.0)$ & & 3 & $73(23.9)$ \\
\hline & 4 & $22(7.2)$ & & 4 & $92(30.2)$ \\
\hline & 5 & $5(10.5)$ & & 5 & $75(24.6)$ \\
\hline & 6 & 35 (11.5) & & & \\
\hline & 7 & $50(16.4)$ & & & \\
\hline & 8 & $61(20.0)$ & & & \\
\hline & 9 & $64(21.0)$ & & & \\
\hline
\end{tabular}


We noted 6.40 \pm 2.32 correct attitudes and 3.52 \pm 1.20 correct practices among our students. Mann-Whitney test demonstrated that female students $(3.86 \pm 1.16)$ had a significantly higher level of correct practice to avoid the disease compared to male students $(3.39 \pm 1.19)(\mathrm{p}<0.01)$, and students coming from rural environments $(6.70 \pm 2.12)$ showed more positive attitude than their counterparts $(6.09 \pm 2.49)(\mathrm{p}<0.05)$. Students living in nuclear families $(3.62 \pm 1.16)$ had better practice than students coming from joint families $(3.21 \pm 1.28)(\mathrm{p}<0.05)$. There was no significant difference in the attitude and personal practice between other groups (Table 7).

Table 7. Positive attitude and good practice of COVID-19 by different characteristics of participants

\begin{tabular}{|c|c|c|}
\hline Characteristics & Attitude, Mean $\pm S D, 6.40 \pm 2.32$ & Practice, Mean \pm SD, $3.52 \pm 1.20$ \\
\hline Gender & $\mathrm{M}-\mathrm{W}$ test value $=8015^{\mathrm{n}}$ & M-W test value $=6964^{* *}$ \\
\hline Male, 224(73.4) & $6.33 \pm 2.21$ & $3.39 \pm 1.19$ \\
\hline Female, 81(26.6) & $6.58 \pm 2.62$ & $3.86 \pm 1.16$ \\
\hline Original residence & M-W test value $=10110^{*}$ & M-W test value $=10868^{\mathrm{n}}$ \\
\hline Urban, 149(48.9) & $6.09 \pm 2.49$ & $3.46 \pm 1.15$ \\
\hline Rural, 156(51.1) & $6.70 \pm 2.12$ & $3.57 \pm 1.25$ \\
\hline Type of family & $\mathrm{M}-\mathrm{W}$ test value $=8376^{\mathrm{n}}$ & M-W test value $=6935^{*}$ \\
\hline Nuclear, 232(76.1) & $6.42 \pm 2.29$ & $3.62 \pm 1.16$ \\
\hline Joint, 73(23.9) & $6.33 \pm 2.43$ & $3.21 \pm 1.28$ \\
\hline Fathers' education & $\mathrm{K}-\mathrm{W}$ test, $\chi^{2}$-value $=6.607^{\mathrm{n}}$ & $\mathrm{K}-\mathrm{W}$ test, $\chi^{2}$-value $=5.009^{\mathrm{n}}$ \\
\hline Uneducated, 25(8.2) & $7.00 \pm 1.78$ & $3.24 \pm 1.23$ \\
\hline Primary, 48(15.7) & $6.94 \pm 2.39$ & $3.83 \pm 1.16$ \\
\hline Secondary, 86(28.2) & $6.24 \pm 2.44$ & $3.49 \pm 1.23$ \\
\hline Higher, 146(47.9) & $6.21 \pm 2.28$ & $3.48 \pm 1.19$ \\
\hline Mothers' education & $\mathrm{K}-\mathrm{W}$ test, $\chi^{2}$-value $=3.507^{\mathrm{n}}$ & K-W test, $\chi^{2}$-value $=2.758^{\mathrm{n}}$ \\
\hline Uneducated, 36(11.8) & $6.78 \pm 2.09$ & $3.22 \pm 1.38$ \\
\hline Primary, 65(21.3) & $6.65 \pm 2.43$ & $3.68 \pm 1.17$ \\
\hline Secondary, 126(41.3) & $6.38 \pm 2.19$ & $3.52 \pm 1.21$ \\
\hline Higher, 78(25.6) & $6.05 \pm 2.52$ & $3.51 \pm 1.13$ \\
\hline
\end{tabular}

N.B.: SD: Standard deviation; M-W: Mann-Whitney; K-W: Kruskal-Wallis; $\chi^{2}$ : Chi-square; *: $5 \%$ level of significance; **: $1 \%$ level of significance; n: non-significance.

\subsection{Perception toward COVID-19}

About half $(54.1 \%)$ of the students felt that they were highly exposed to COVID-19. Most of the students were either extremely or very worried about being infected $(66.3 \%)$, and about the consequence of having the infection $(67.9 \%)$. Many students were either very fearful $(32.5 \%)$ or fearful $(37.7 \%)$ about this infection. Many of the students admitted that the disease had either greatly or moderately impacted their daily routine $(50.5 \%)$, studies $(40.0 \%)$, financial status $(37.4 \%)$, family routine $(48.2 \%)$, overseas traveling $(76.7 \%)$, study fieldwork $(56.0 \%)$, and restricted their meetings with friends $(54.1 \%)$ and families/relatives $(51.9 \%)$ (Table 8$)$.

Table 8. Perception of students toward COVID-19 and about its impact

\begin{tabular}{|c|c|c|c|c|}
\hline Are you highly exposed to COVID-19? & $\begin{array}{l}\text { Yes, N (\%) } \\
165(54.1)\end{array}$ & $\begin{array}{l}\text { No, } \mathbf{N}(\%) \\
79(25.9)\end{array}$ & $\begin{array}{l}\text { Not at all, } \mathbf{N}(\%) \\
61(20.0)\end{array}$ & \\
\hline & $\begin{array}{l}\text { Extremely } \\
\mathbf{N}(\%)\end{array}$ & $\begin{array}{l}\text { Very } \\
\text { N }(\%)\end{array}$ & $\begin{array}{l}\text { Moderately } \\
\text { N }(\%)\end{array}$ & $\begin{array}{l}\text { Not at all } \\
\mathbf{N}(\%)\end{array}$ \\
\hline $\begin{array}{l}\text { How worried are you about getting } \\
\text { COVID-19? }\end{array}$ & $110(36.1)$ & $92(30.2)$ & $84(27.5)$ & $19(6.2)$ \\
\hline $\begin{array}{l}\text { How worried are you about the } \\
\text { consequences of getting COVID-19? }\end{array}$ & $96(31.5)$ & $111(36.4)$ & $84(27.5)$ & $14(4.6)$ \\
\hline How is your fear level toward COVID-19? & $\begin{array}{c}\text { Very fearful, N (\%) } \\
99(32.5)\end{array}$ & $\begin{array}{c}\text { Fearful, N (\%) } \\
115(37.7)\end{array}$ & $\begin{array}{l}\text { Slightly fearful, } \mathbf{N}(\%) \\
67(22.0)\end{array}$ & $\begin{array}{c}\text { Not at all fearful, } \mathbf{N}(\%) \\
24(7.9)\end{array}$ \\
\hline
\end{tabular}




\begin{tabular}{|c|c|c|c|c|}
\hline \multicolumn{5}{|c|}{ Perception about the impact of COVID-19 } \\
\hline & Great extent & Moderately & Very little & Not at all \\
\hline The COVID-19 outbreak has affected my daily routine & $70(23.0)$ & $84(27.5)$ & $81(26.6)$ & $70(23.0)$ \\
\hline The COVID-19 outbreak has affected my study & $70(23.0)$ & $52(17.0)$ & $68(22.3)$ & $115(37.7)$ \\
\hline The COVID-19 outbreak has affected my financial & $65(21.3)$ & $49(16.1)$ & $60(19.7)$ & 131(43.0) \\
\hline The COVID-19 outbreak has affected my family's daily routine & $55(18.0)$ & $92(30.2)$ & $69(22.6)$ & $89(29.2)$ \\
\hline The COVID-19 outbreak has affected my travel abroad & 181(59.3) & $53(17.4)$ & $36(11.8)$ & $35(11.5)$ \\
\hline The COVID-19 outbreak has affected my study fieldwork & 102(33.4) & $69(22.6)$ & $63(20.7)$ & $71(23.3)$ \\
\hline The COVID-19 outbreak has restricted my leisure time of meeting friends & $95(31.1)$ & $70(23.0)$ & $82(26.9)$ & $58(19.0)$ \\
\hline $\begin{array}{l}\text { The COVID-19 outbreak has restrict my leisure time of meeting family and } \\
\text { relatives }\end{array}$ & $88(28.9)$ & $70(23.0)$ & $55(18.0)$ & $92(30.2)$ \\
\hline
\end{tabular}

\section{Discussion}

Hundreds of Bangladeshi students, businessmen, and tourists started to return home from China in early January 2020 just after the COVID-19 outbreak there, and the government started to screen them at the ports of entry [47]. This was followed by Bangladeshi people returning from other countries with the increasing spread of the disease in the world. Problems related to the screening, health check-ups, and quarantine measures for these home-coming people created huge debates and these were covered by the national and regional news media as well as social media. Being the more progressive, knowledgeable and resourceful segment of the population, University students were supposed to be better informed about this global disaster, and would probably serve as the target population to initiate any prevention or remedial measures to reduce the overall damage of COVID-19. Knowledge, attitude and perception are essential factors associated with the behavioural modification that may eventually prove to be the main strategy to curb the pandemic [47]. This was the main reason we conducted this study, and to the best of our knowledge, it is the first study designed to evaluate the knowledge, attitude, practice and perception of the COVID-19 outbreak among University students in Bangladesh.

\subsection{Profile of the Respondents}

Students of Rajshahi University come from all parts of the country and encompass all sections of the society. We could consider the students to represent all the communities in the country [27].

\subsection{Knowledge on COVID-19}

The level of knowledge of our University students on the signs and symptoms of COVID-19, the preventive measures and its mode of transmission was lower than that of the medical students from China, Iran and Pakistan [1315], as well as medical and non-medical university students from Jordan [16]. It was also noted to be lower than secondary school students from Italy [17], and the general public of countries like Egypt, India, Nigeria, Malaysia, Peru, and China [18-21, 23, 48]. One of the possible factors would be the fact that the study was conducted at the very early stage of the pandemic, and at that stage, the country was not seriously affected by it. However, since Bangladesh is a very densely populated country, coupling with very limited medical resources, we can expect the University students would be very concerned about the potential impact of this rapidly developing global crisis. Our study results should trigger the alarm for the government to seriously review existing strategies to disseminate accurate and up-todate knowledge to the general population.

\subsection{Attitude}

Our study also showed that about $60 \%$ of the students had a positive attitude towards the preventive measures against the disease, compared to $73.81 \%$ among students in China [13]. The attitude was also poorer than that of medical students from Pakistan [15] and mixed students from Jordan [16]. The attitude was also lower than that of the general population of Egypt [18], and India [19]. Attitude towards disease is heavily influenced by the awareness and general knowledge about the condition, and this would probably be the most important contributing factor

\subsection{Personal Practice}

About $40 \%$ of our students did not wear face masks in public places. Many reasons may influence the rate of using a mask, but in our opinion lack of awareness, unavailability and higher cost might be the main contributing factors in Bangladesh. More than one-third of the students were not interested in staying home and avoiding crowded places. Social, cultural and religious practices in this country frequently require people to congregate for ceremonies or prayers, and this might discourage some of the students to remain at home. In China, $87.94 \%$ of university students had pro-active behaviors [13]. The practice of preventive measures was also common among Iranian medical students [14], Jordanian medical and non-medical university students [16], and Italian secondary students [17]. The practice of 
personal hygiene is relatively low in Bangladesh; only $40 \%$ of the general populations wash their hands with soap and water, and only $35 \%$ of schools have facilities of washing hands with soap and water [49]. Our study noted that female students coming from nuclear families were more likely to practice personal hygiene compared to male students from joint families. Two studies from China showed similar findings to our study $[13,48]$.

\subsection{Perception}

Only half of the students felt that they were exposed to the infection; however, more than half of them were either extremely or very worried about the disease and its consequences. Half of the students felt that the disease had either greatly or moderately impacted their daily activities, but affected their studies, financial status and family activities to a lesser extent. Our study was performed during the period when the national lockdown was not initiated, and even at the later stage, only the teaching institutions were closed. A high level of disease-related knowledge and moderate risk perception was reported among Iranian medical students [14]. Since this is a novel disease where many aspects of its behaviour have not been clearly understood, we would anticipate much false or unconfirmed information circulating among the public. A study reported a list of misconceptions about COVID-19 among the general population of India [22]. Religious and cultural beliefs may directly or indirectly influence the perception of this disease, and they may either contribute towards or against the control of the pandemic. Mentionable, the University authorities did not take any initiative to increase the knowledge or improve attitude, preventive practice and perception of the students regarding COVID-19. The University has not organized any activity or campaign to create awareness or promote the practice of healthy behaviours among the students or academic staff. The most likely sources of information for the students were print, electronic and social media or the internet, but we do not have any means to validate this.

\subsection{Strength and Limitation of this Study}

Perhaps this was the first time we attempted to survey on knowledge, attitude, practice and perception among nonmedical university students at the very early stage of the pandemic in Bangladesh. The main limitation of our study was the small sample size. The unexpected closure of teaching institutions (including the Universities) and subsequently national lockdown halted our effort to obtain the targeted sample population and proper gender distribution. Due to time constraints, a multi-centre study including students from other universities was not feasible. Another limitation was that all the students were from the science faculty. A broader distribution of academic fields would be preferable. Taking all the students to a classroom for filling up the questionnaire might not be the most conducive procedure.

\section{Conclusion}

Our study shows that the overall knowledge, attitude and behaviour of the educated young population of Bangladesh regarding COVID-19 were poor despite the urgency and broad media coverage during the early stage of the pandemic. This fact should be taken as a baseline reference for urgent public health education to mitigate or control the pandemic in the country. The University authorities should also take imitative for increasing general knowledge on COVID-19 among the university students and promote a positive attitude, perception and preventive measures among them. The lower levels of knowledge, attitude, perception and preventive measures among the university students indicate that the situation might be worse among the general population. Since behavioural modification is very important in preventing and controlling any epidemic/pandemic, the government and the concerned authorities should take serious action in this regard.

\section{Declarations}

\subsection{Author Contributions}

Conceptualization: M.A.W. and M.G.H.; methodology: M.A.W. and M.G.H.; software: A.S.M.A.M. and M.K.I.; formal analysis: M.G.H. and M.A.W.; investigation: A.S.M.A.M. and M.A.R.; resources, M.G.H., S.A., L.L.L. and S.M.; data curation, A.S.M.A.M. and M.A.W.; writing - original draft preparation, M.A.W.; writing-review and editing, M.A.W., M.G.H., S.M., L.L.L. and S.A. All authors have read and agreed to the published version of the manuscript.

\subsection{Funding}

The authors received no financial support for the research, authorship, and/or publication of this article.

\subsection{Acknowledgements}

The authors gratefully acknowledge the authorities of the selected departments, University of Rajshahi, Bangladesh for providing information about the students. The authors would also like to express their sincere gratitude to all the participants for providing their information. 


\subsection{Ethical Approval}

The ethical clearance for this study was obtained from the Institutional Animal, Medical Ethics, Biosafety and Biosecurity Committee (IAMEBBC) for Experimentation on Animal, Human, Microbes and Living Natural Sources, Institute of Biological Sciences, University of Rajshahi, Bangladesh (Memo No: 120/ 320/ IAMEBBC/ IBSc, dated April 11, 2019). Written and informed consent of every participant was taken.

\subsection{Data Availability Statement}

The data presented in this study are available on request from the corresponding author.

\subsection{Conflict of Interest}

The authors declare that they have no known competing financial interests or personal relationships that could have appeared to influence the work reported in this paper.

\section{References}

[1] Wuhan Municipal Health and Health Commission's briefing on the current pneumonia epidemic situation in our city 2019. Available online: https://crofsblogs.typepad.com/h5n1/2019/12/wuhan-municipal-health-commissionannounces-pneumonia-epidemic.html (accessed on 27 March, 2020).

[2] Naming the coronavirus disease (COVID-19) and the virus that causes it. Available online: https://www.who.int/emergencies/diseases/novel-coronavirus-2019/technical-guidance/naming-the-coronavirusdisease-(covid-2019)-and-the-virus-that-causes-it (accessed on 27 March, 2020).

[3] Sohrabi, C., Alsafi, Z., O’Neill, N., Khan, M., Kerwan, A., Al-Jabir, A., ... Agha, R. (2020). World Health Organization declares global emergency: A review of the 2019 novel coronavirus (COVID-19). International Journal of Surgery, 76, 71-76. doi:10.1016/j.ijsu.2020.02.034.

[4] The Novel Coronavirus Pneumonia Emergency Response Epidemiology Team, Weekly Surveillance (Chinese Centers for Disease Control and Prevention). Available online: http://weekly.chinacdc.cn/en/article/id/e53946e2-c6c4-41e9-9a9bfea8db1a8f51 (accessed on 27 March, 2020).

[5] Corona Virus Resource Centre, John Hopkins University and Medicine. Available online: Available online: https://coronavirus.jhu.edu/map.html (accessed on May 26, 2020).

[6] Bassetti, M., Vena, A., \& Giacobbe, D. R. (2020). The novel Chinese coronavirus (2019 - nCoV) infections: Challenges for fighting the storm. European Journal of Clinical Investigation, 50(3). doi:10.1111/eci.13209.

[7] Ji, W., Wang, W., Zhao, X., Zai, J., \& Li, X. (2020). Cross-species transmission of the newly identified coronavirus 2019-nCoV. Journal of Medical Virology, 92(4), 433-440. doi:10.1002/jmv.25682.

[8] Shereen, M. A., Khan, S., Kazmi, A., Bashir, N., \& Siddique, R. (2020). COVID-19 infection: Emergence, transmission, and characteristics of human coronaviruses. Journal of Advanced Research, 24, 91-98. doi:10.1016/j.jare.2020.03.005.

[9] Carlos, W. G., Dela Cruz, C. S., Cao, B., Pasnick, S., \& Jamil, S. (2020). Novel Wuhan (2019-nCoV) Coronavirus. American Journal of Respiratory and Critical Care Medicine, 201(4), P7-P8. doi:10.1164/rccm.2014p7.

[10] Wu, P., Hao, X., Lau, E. H. Y., Wong, J. Y., Leung, K. S. M., Wu, J. T., ... Leung, G. M. (2020). Real-time tentative assessment of the epidemiological characteristics of novel coronavirus infections in Wuhan, China, as at 22 January 2020. Euro Surveillance, 25(3). doi:10.2807/1560-7917.es.2020.25.3.2000044.

[11] World Health Organization, Corona Virus. Available online: https://www.who.int/health-topics/coronavirus\#tab=tab_1 (accessed on 27 March, 2020).

[12] UNICEF. Coronavirus disease (COVID-19): What parents should know. Available online: https://www.unicef.org/bangladesh/en/coronavirus-disease-covid-19-what-parents-should-know (accessed on 27 March, 2020).

[13] Peng, Y., Pei, C., Zheng, Y., Wang, J., Zhang, K., Zheng, Z., \& Zhu, P. (2020). Knowledge, Attitude and Practice Associated with COVID-19 among University Students: a Cross-Sectional Survey in China. Research Square Preprint. doi:10.21203/rs.3.rs-21185/v1.

[14] Taghrir, M. H., Borazjani, R., \& Shiraly, R. (2020). COVID-19 and Iranian Medical Students; A Survey on Their RelatedKnowledge, Preventive Behaviors and Risk Perception. Archives of Iranian Medicine, 23(4), $249-254$. doi:10.34172/aim.2020.06.

[15] Ikhaq, A., Bint E Riaz, H., Bashir, I., \& Ijaz, F. (2020). Awareness and Attitude of Undergraduate Medical Students towards 2019-novel Corona virus. Pakistan Journal of Medical Sciences, 36(COVID19-S4). doi:10.12669/pjms.36.covid19-s4.2636.

[16] Alzoubi, H., Alnawaiseh, N., Al-Mnayyis, A., Lubad, M. A., Aqel, A., \& Al-Shagahin, H. (2020). COVID-19-knowledge, attitude and practice among medical and non-medical University Students in Jordan. J Pure Appl Microbiol, 14(1), 17-24. 
[17] Souli, D., \& Dilucca, M. (2020). Knowledge, attitude and practice of secondary school students toward COVID-19 epidemic in Italy: a cross selectional study. BioRxiv Preprint. doi:10.1101/2020.05.08.084236.

[18] Abdelhafiz, A. S., Mohammed, Z., Ibrahim, M. E., Ziady, H. H., Alorabi, M., Ayyad, M., \& Sultan, E. A. (2020). Knowledge, Perceptions, and Attitude of Egyptians Towards the Novel Coronavirus Disease (COVID-19). Journal of Community Health, 45(5), 881-890. doi:10.1007/s10900-020-00827-7.

[19] Tomar, B. S., Singh, P., Suman, S., Raj, P., Nathiya, D., Tripathi, S., \& Chauhan, D. S. (2020). Indian community's Knowledge, Attitude \& Practice towards COVID-19. MedRxiv Preprint. doi:10.1101/2020.05.05.20092122.

[20] Olapegba, P. O., Ayandele, O., Kolawole, S. O., Oguntayo, R., Gandi, J. C., Dangiwa, A. L., ... Iorfa, S. K. (2020). A Preliminary Assessment of Novel Coronavirus (COVID-19) Knowledge and Perceptions in Nigeria. SSRN Electronic Journal. doi:10.2139/ssrn.3584408.

[21] Azlan, A. A., Hamzah, M. R., Sern, T. J., Ayub, S. H., \& Mohamad, E. (2020). Public knowledge, attitudes and practices towards COVID-19: A cross-sectional study in Malaysia. MedRxiv Preprint. doi:10.1101/2020.04.29.20085563.

[22] Nazli, T., Heena, Raheem, A., \& Kishore, J. (2020). Perceptions and Practices of the Adult Population in Response to SARSCoV-2 Pandemic in India. Epidemiology International, 05(02), 10-16. doi:10.24321/2455.7048.202011.

[23] Zegarra-Valdivia, J., Chino Vilca, B. N., \& Ames-Guerrero, R. J. (2020). Knowledge, perception and attitudes in Regard to COVID-19 Pandemic in Peruvian Population. PsyArXiv. doi:10.31234/osf.io/kr9ya.

[24] IEDCR (Institute of Epidemiology, Disease Control and Research). Covid-19 Status Bangladesh. Available online: https://www.iedcr.gov.bd/ (accessed on 27 March, 2020).

[25] Dhaka Tribune. (2020). Bangladesh coronavirus test rate lowest in world. Available online: https://www.dhakatribune.com/bangladesh/2020/04/01/only-one-in-100-000-tested-for-coronavirus-in-bangladesh (accessed on 01 April, 2020).

[26] Bangladesh Bureau of Statistics. (2015). Complimentary population monograph of Bangladesh. Bangladesh Bureau of Statistics (BBS), Dhaka, November 2015. Available online: http://203.112.218.65:8008/WebTestApplication/userfiles/Image/ PopMonographs/Volume-7_PDV.pdf (Accessed on April 6, 2020).

[27] Bangladesh literacy rate: Available online: http://uis.unesco.org/en/country/bd (accessed on April 6, 2020).

[28] UNICEF, Bangladesh. Safer sanitation and hygiene. Available online: https://www.unicef.org/bangladesh/en/better-accesssafe-drinking-water/safer-sanitation-and-hygiene (accessed on April 6, 2020).

[29] Pattanaik, S. S. (2020). Covid-19 and Bangladesh: Looming Crisis in the Horizon. Manohar Parrikar Institute for Defence Studies and Analyses, New Delhi. Available online: https://idsa.in/idsacomments/covid19-bangladesh-smruti-090420 (accessed on April 6, 2020).

[30] Hasan, R. (2020). Shambolic: 142 Italy returnees allowed to go home after day-long mismanagement, The Daily Star, 15 March 2020. Available online: https://www.thedailystar.net/frontpage/news/shambolic-1880866 (accessed on April 6, 2020).

[31] Alif, A. (2020). Covid-19 pandemic: Testing remains low despite having enough kits in stock. Dhaka Tribune. Available online: https://www.dhakatribune.com/bangladesh/2020/03/29/covid-19-pandemic-testing-remains-low-despite-having-enough -kits-in-stock (accessed on 30 March, 2020).

[32] Ar Rafee, A. (2020). The COVID-19 Outbreak: How Has Bangladesh Fared? Stimson (2020). Available online: https://www.stimson.org/2020/the-covid-19-outbreak-how-has-bangladesh-fared/ (accessed on 30 March, 2020).

[33] Ramachandran, S. (2020). The COVID-19 Catastrophe in Bangladesh. The Diplomat. Available online: https://thediplomat.com/2020/04/the-covid-19-catastrophe-in-bangladesh/ (accessed on April 29, 2020).

[35] AFP. (2020). Massive Bangladesh coronavirus prayer gathering sparks outcry. Available online: https://news.yahoo.com/massive-bangladesh-coronavirus-prayer-gathering-sparks-outcry-193538973.html (accessed on 19 March, 2020).

[36] Ahamad, R. and Rashid, M. (2020). People back in lax mode, violating social distancing. Available online: https://epaper.newagebd.net/31-03-2020/8 (accessed on 31 March, 2020).

[37] Person, B., Sy, F., Holton, K., Govert, B., Liang, A., ... Garza, B. (2004). Fear and Stigma: The Epidemic within the SARS Outbreak. Emerging Infectious Diseases, 10(2), 358-363. doi:10.3201/eid1002.030750.

[38] Ghosh, B., Sarkar, S., Sepay, N., Das, K., Das, S., \& Dastidar, S. G. (2021). Factors for COVID-19 Infection that Govern the Severity of Illness. SciMedicine Journal, 3(2), 177-197. doi:10.28991/scimedj-2021-0302-9.

[39] Tegally, H., Wilkinson, E., Giovanetti, M., Iranzadeh, A., Fonseca, V., Giandhari, J., ... de Oliveira, T. (2021). Detection of a SARS-CoV-2 variant of concern in South Africa. Nature, 592(7854), 438-443. doi:10.1038/s41586-021-03402-9. 
[40] Dao, T. L., Hoang, V. T., \& Gautret, P. (2020). Recurrence of SARS-CoV-2 viral RNA in recovered COVID-19 patients: a narrative review. European Journal of Clinical Microbiology \& Infectious Diseases, 40(1), 13-25. doi:10.1007/s10096-02004088-z.

[41] Banik, R., Rahman, M., Sikder, M. T., Rahman, Q. M., \& Pranta, M. U. R. (2021). Knowledge, attitudes, and practices related to the COVID-19 pandemic among Bangladeshi youth: a web-based cross-sectional analysis. Journal of Public Health. doi:10.1007/s10389-020-01432-7.

[42] Islam, S., Emran, G. I., Rahman, E., Banik, R., Sikder, T., Smith, L., \& Hossain, S. (2020). Knowledge, attitudes and practices associated with the COVID-19 among slum dwellers resided in Dhaka City: a Bangladeshi interview-based survey. Journal of Public Health, 43(1), 13-25. doi:10.1093/pubmed/fdaa182.

[43] Hossain, M. A., Rashid, M. U. B., Khan, M. A. S., Sayeed, S., Kader, M. A., \& Hawlader, M. D. H. (2021). Healthcare Workers' Knowledge, Attitude, and Practice Regarding Personal Protective Equipment for the Prevention of COVID-19. Journal of Multidisciplinary Healthcare, Volume 14, 229-238. doi:10.2147/jmdh.s293717.

[44] Rana, M., Sayem, A., Karim, R., Islam, N., Islam, R., Zaman, T. K., \& Hossain, G. (2015). Assessment of knowledge regarding tuberculosis among non-medical university students in Bangladesh: a cross-sectional study. BMC Public Health, 15(1). doi:10.1186/s12889-015-2071-0.

[45] WHO. (2020). Survey Tool and Guidance (Rapid, simple, flexible behavioural insights on COVID-19). Available online: https://www.euro.who.int/_data/assets/pdf_file/0007/436705/COVID-19-survey-tool-and-guidance.pdf (accessed on 10 August, 2020).

[46] Etikan, I. (2017). Combination of Probability Random Sampling Method with Non Probability Random Sampling Method (Sampling Versus Sampling Methods). Biometrics \& Biostatistics International Journal, 5(6). doi:10.15406/bbij.2017.05.00148.

[47] Maswood, M. H., \& Hossain, S. (2020). Bangladesh at high risk of coronavirus. The New Age, Bangladesh. Available online: https://www.newagebd.net/article/101292/bangladesh-at-high-risk-of-coronavirus (accessed on 20 March, 2020).

[48] Zhong, B.-L., Luo, W., Li, H.-M., Zhang, Q.-Q., Liu, X.-G., Li, W.-T., \& Li, Y. (2020). Knowledge, attitudes, and practices towards COVID-19 among Chinese residents during the rapid rise period of the COVID-19 outbreak: a quick online crosssectional survey. International Journal of Biological Sciences, 16(10), 1745-1752. doi:10.7150/ijbs.45221.

[49] Bangladesh National Hygiene Baseline Survey, Preliminary Report (2014). Available online: https://washmatters.wateraid.org/publications/bangladesh-national-hygiene-baseline-survey-preliminary-report-2014 (accessed on 20 March, 2020). 